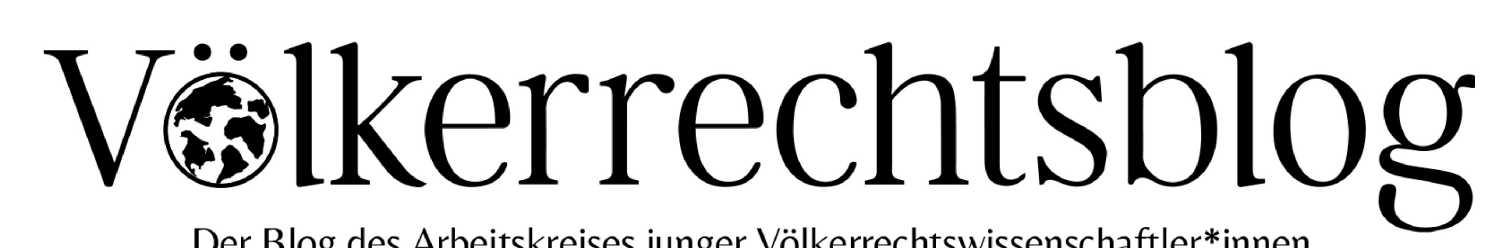

Der Blog des Arbeitskreises junger Völkerrechtswissenschaftler*innen

E Navigation

Q

SYMPOSIUM THE PROMISES OF INTERNATIONAL LAW AND SOCIETY

\title{
Juridification of the right to development in India
}

ANNA-LENA WOLF - 9 September, 2015

宫 Print

0 f $08^{+} p$

Anna-Lena Wolf

In my paper for the legal sociology conference in Berlin, I argue that the right to development, though a non-legally binding declaration, is indirectly implemented in the Indian legal system through case law - a process which I interpret as a juridification of the right to development (for the term juridification see Blichner and Molander 2008). This argument challenges the distinction between legally binding treaties and non-legally binding instruments in international law around which many of the controversies regarding the right to development arise. Furthermore, the paper approaches the question of how different concepts of development and correlated ideas of justice are negotiated 
in the genesis of interpretations of the right to development in Indian case law.

\section{The right to development}

The United Nations declaration on the right to development (1986) declares development a human right and redefines development as a participatory process 'in which all human rights and fundamental freedoms can be fully realized.' (Art. 1) This definition fundamentally challenges the dominant interpretation of development in terms of economic growth. Ever since the declaration on the right to development, its moral and legal justification, justiciability and chief contents have been much debated. Proponents declare the right to development as one of the core human rights (e.g. Sengupta 2001). Critics, on the other hand, argue that human rights can, by definition, not include collective rights and that socalled 'third generation human rights' endanger the indivisibility of human rights. Besides moral doubts, the right's legal justification and justiciability is questioned because right-holders, duty-bearers, rights-content and related binding obligations are seen to be ill-defined (cf. Donnelly 1985).

The discourse is, however, limited to consider the right to development from a perspective of international law. Thereby, its non-legally binding nature is either seen as a good reason to criticize and condemn it or the problem is circumvented by broadening the definition of rights to rights with 'imperfect' legal obligations. The right to development is then seen limited to provide 'imperfect' legal obligations in terms of its indirect implementation through international or national development policies for instance. Both 
perspectives, I argue, fail to notice the usage of the right to development in national legal systems through case law.

\section{Juridification of the right to development in India}

Taking India as an example, I illustrate the interpretation, use, and juridification of the right to development in case law. India constitutes an interesting case study because its common law system is largely case-centered and reliant upon judge's interpretations and has a distinct occurrence of judicial activism. I claim a juridification of the right to development through Indian judges who have shown an increased inclination to refer to the United Nations declaration on the right to development in their legal argumentation to solve judicial conflicts and through the interpretation of the right to development as part of Article 21 ('right to life') of the Indian constitution. These cases, subsequently, create precedents that are followed by other judges.

The application of the right to development in India mainly reflects a legal argument for the protection of minority rights, such as women's rights, Dalit rights and Adivasi rights in cases on affirmative action in education, land acquisition and labour rights. For instance, in a judgment on the constitutionality of customary law in Bihar in 1996, which had until then excluded tribal women from the inheritance of property, the right to development was used to argue for an amendment of the discriminatory law '...to ensure that women have an active role in the development process. Appropriate economic and social reforms should be carried out with a view to eradicate all social injustice' (Madhu Kishwar vs. State of Bihar). There is, however, a risk of misuse involved as exemplified by a judgment in 2010 on the 
land acquisition for the construction of the Yamuna Expressway. There it was argued that '...the scales of justice must tilt towards the right to development of the millions who will be benefited from the road and the development of the area, as against the human rights of 35 petitioners therein...' (Nand Kishore vs. State of U.P.). In my mind, this interpretation, uses the right to development for a utilitarian legal argument to justify human rights restrictions.

\section{Conclusion}

To sum up, the dominant definition of development in terms of economic growth is challenged by the United Nations declaration on the right to development which redefines development as the fulfilment of all human rights for all people. The study of the juridification of the right to development in Indian case law showed that the right can either become an instrument for the protection of minority rights when it is used according to its redefinition of development as a human right. There is, on the other hand, a danger involved when the redefinition of development as put forth in the declaration is turned towards its exact opposite and the right to development, thereby, becomes an instrument to justify human rights restrictions of particular groups of people for the purpose of the public interest and development of the people of India.

Anna-Lena Wolf, M.A. is a PhD candidate and research assistant at the Institute of Social Anthropology, University of Bern, Switzerland.

This post is part of our conference symposium "The Promises of International Law and Society". Other posts in this series can be accessed here. 
ISSN 2510-2567

Tags: India, Juridification

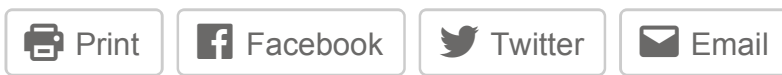

\section{Related}

European patients and African remedies

19 January, 2015

In "Discussion"
A Pebble in the Shoe: Assessing International Uses of Do No Harm 15 October, 2014 In "Discussion"
Blackmarketing

"Bundeswehr"

Weapons in Northern Iraq:

25 July, 2016

In "Discussion"

PREVIOUS POST

¿ Should we call a lawyer?

NEXT POST

Towards Post-Western Investment Law?

\section{No Comment}

Leave a reply

Logged in as ajv2016. Log out? 
Notify me of follow-up comments by email.

$\square$ Notify me of new posts by email. 